KS. PIOTR NATANEK

\title{
POGRANICZE KOŚCIELNE DIECEZJI KRAKOWSKIEJ I WROCLAWSKIEJ NA ŚLĄSKU NA PRZELOMIE XVIII I XIX WIEKU
}

Zagadnienie to obejmuje tereny dekanatów bytomskiego i pszczyńskiego na Gómym Śląsku (53 parafie - 1815 r.) i tereny dekanatów siewierskiego i lelowskiego w okręgu Częstochowy i Nowego Śląska (Siewierz, Kłobuck, Pilica; 46 parafii i 3 filie -1807 r.) $)^{1}$.

Wszystkie te dekanaty wchodziły w obręb diecezji krakowskiej, choć większość z nich była poza granicami Rzeczypospolitej. Przyczyn tego należy szukać jeszcze w czasach rozbicia dzielnicowego. W drodze przewrotu władzę przejął Kazimierz Sprawiedliwy ${ }^{2}$ i to wlaśnie on ofiarował w 1179 r. swojemu sojusznikowi Mieszkowi Plątonogiemu (księciu raciborskiemu) zachodnie ziemie Małopolski z grodami: Bytomiem, Oświęcimiem i Siewierzem ${ }^{3}$. W 1443 r. (30 grudnia) księstwo siewierskie odkupił kard. Zbigniew Oleśnicki od Wacława cieszyńskiego $^{4}$. Odtąd księstwo było prywatną własnością biskupów krakowskich, choć położoną poza granicami Rzeczypospolitej. Dopiero Sejm Wielki 17 VII 1789 r. uchwalił włączenie go w obręb terytorium Rzeczypospolitej ${ }^{5}$. Księstwo oświęcimskie zostało wykupione przez Koronę w 1457 r. ${ }^{6}$ Od XIV w. księstwa piastowskie stopniowo przechodziły w zależność lenną na rzecz Czech. Do roku 1741 cały Śląsk był pod panowaniem Austrii. Dopiero po wojnie śląskiej między Prusami a Austrią od 1741 r. Ślask przeszedł pod panowanie Prus. W tę historię wpisane były również dzieje dekanatów bytomskiego i pszczyńskiego wchodzących

${ }^{1}$ B. K u mor, Ustrój i organizacja Kościola polskiego w okresie niewoli narodowej 1772-19/8, Kraków 1980, s. 182-185.

${ }^{2}$ J. W y ro zu mski, Wielka historia Polski. Dzieje Polski Piastowskiej (VIII w. - 1370), Kraków 1999, t. 2, s. 152-155.

${ }^{3}$ J. L a b e r s c h e k, $Z$ dziejów Siewierza i ziemi siewierskiej do końca XIII w., [w:] Siewierz. Czeladź. Koziegłowy. Studia z dziejów księstwa siewierskiego, red. F. Kiryk, Katowice 1994, s. 119.

${ }^{4} \mathrm{~K}$. B a c z k o w s k i, Wielka historia Polski. Dzieje Polski późnośredniowiecznej (1370-1506), Kraków 1999, t. 3, s. 158-159; Z. Nog a, Osadnictwo i stosunki wlasnościowe w księstwie siewierskim do 1790 r., [w:] Siewierz. Czelaź. Koziegtowy.., dz. cyt., s. 166.

5 J. W y s o c k i, Dzieje Kościota w Rzeczpospolitej w okresie stanisławowskim, [w:] Historia Kościola w Polsce, red. B. Kumor, Z. Obertyński, Poznań-Warszawa 1979, t. 2, cz. 1, s. 47.

${ }^{6}$ K. B a c z k ow s k i, Wielka historia Polski.., dz. cyt., s. 206. 
w skład archidiakonatu krakowskiego?. W 1786 r. dekanat bytomski obejmowały następujące parafie: Bytom (2400 komunikowanych w czasie Wielkanocy), Bileszowice (440), Biskupice (820), Bogucice (1020), Chorzów (690), Dziećkowice (381), Kamień (974), Kochłowice (783), Lubsza (1400), Michałkowice (420), Miechowice (ok. 412), Mikluczyce (420), Mysłowice (3086), Piekary (362), Radzionków (771), Repty (942), Stare Tarnowice (969), Tarnowskie Góry (1130), Woźniki (800), Zyglin $(1168)^{8}$. Ogółem w dekanacie bytomskim było w tym czasie 20380 komunikowanych w części Śląska pruskiego ${ }^{9}$. W 1786 r. teren dekanatu pszczyńskiego obejmowały następujące parafie: Bieruń (1500 - liczba komunikowanych), Bojszowy (450), Brzeście (?), Chełm (600), Ćwiklice (400), Goczałkowice (?), Lędziny (1300), Łąka (556), Miedzna (1300), Mikołów (?), Mokre (150), Orzesze, filia Woszczyc (?), Poręba Wielka (?), Pszczyna (2000), Sisiec (700), Studzinoka (?), Strumień (?), Tychy (700), Wisła Niemiecka (250), Woszczyce (?), Zdziechowice (225), Zwiekliczyce $(225)^{10}$. Tu trzeba nadmienić, że do 1747 r. księstwo siewierskie należało do dekanatu bytomskiego. Za czasów dziekana bytomskiego Michała Staporkiewicza (23 V 1747 - 15 III 1748) biskup diecezji krakowskiej Andrzej Załuski podzielił dekanat bytomski na dwie części. Nowy siewierski obejmował terytorium księstwa siewierskiego, będącego prywatną własnością biskupów krakowskich. Przy dekanacie bytomskim pozostały wszystkie te parafie, które wówczas znajdowały się już na terytorium państwa pruskiego $^{11}$.

Już w 1743 r. władze pruskie podjęły starania o przekazanie terenów dekanatów bytomskiego i pszczyńskiego pod jurysdykcję biskupa wroclawskiego. Ze względu na niepewną jeszcze wówczas przynależność Śląska władze pruskie zaniechały tego planu. 14 IV 1744 r. władza pruska przedstawiła biskupowi krakowskiemu Janowi Lipskiemu warunki pełnienia urzędu na tym terytorium. Jednak już 20 X 1747 r. w liście do biskupa wrocławskiego Filipa Schaffgotscha rząd pruski zamierzał utworzyć dla tych dekanatów osobny wikariat generalny. Ze względu na opór biskupa krakowskiego Andrzeja Załuskiego projekt ten upadł. Kolejnym zamierzeniem rzadowym było utworzenie tu komisariatu biskupiego (oficjalat okręgowy). Ten plan również upadł. W $1750 \mathrm{r}$. Prusy podjęły starania mianowania przez Stolicę Apostolską na te ziemie sędziów prosynodalnych. Podobnych sędziów chciały Prusy zyskać dla pruskiej części diecezji ołomunieckiej (okręg Głubczyc) i archidiecezji praskiej (okręg Kłodzka). Papież Benedykt XIV zaproponował w $1751 \mathrm{r}$. rozwiązanie pośrednie tego problemu i powołanie sędziów prosynodalnych uzależnił od zgody biskupa krakowskiego. Andrzej Zaluski był przeciwny temu rozwiązaniu. Mimo takiego przesilenia i próby sił to właśnie biskup krakowski w tym czasie obsadzał tu parafie. I tak było w tym czasie w przypadku paratii 'Tarnowskie Góry (18 III 1746, 1 VI 1750, 28 VI 1751), Chorzów i Bytom (28 VI 1746) ${ }^{12}$.

${ }^{7} \mathrm{P}$. N a t a n e k, Organizacja terytorialna diecezji krakowskiej w latach 1795-1939, Kraków 1995 , s. 13.

${ }^{8}$ B. K u m o r, Dzieje diecezji krakowskiej do roku 1795, Kraków 1998, t. 1, s. 133-134.

${ }^{9}$ Tamże, t. 1 , s. 134.

${ }^{10}$ Tamże, s. 134-135.

${ }^{11}$ Tamże, t. 4, s. 135.

${ }^{12}$ Tamże, t. 1 , s. 130-132. 
Ta zachowawcza polityka Prus wynikała z przyszłej niepewności politycznej Śląska. W latach 1740-1763 byly prowadzone trzy wojny o Sląsk między Austrią a Prusami (I: 1740-1742, II: 1744-1745, III: 1756-1763). Dopiero traktat w Hbertsburgu w Austrii przyznawał ostatecznie Śląsk Prusom ${ }^{13}$. Wspomniany biskup wrocławski Schaffgotsch stanął po stronie Austrii, zgłaszając sprzeciw wobec roszczeń Prus ${ }^{14}$. To spowodowało, ze musiał opuścić Wrocław (1766). Dlatego też dopiero 4 IX 1788 r. Stolica Apostolska wyznaczyła koadiutora na Wrocław w osobie Józefa Hohenlohego, który dopiero w 1795 r. po śmierci bp. Schaffgotscha mógł objąć biskupstwo wrocławskie ${ }^{15}$. Jednocześnie po stronie austriackiej biskup wrocławski utrzymał swoją jurysdykcję na Śląsku Cieszyńskim i w okolicach Gluchołaz. Z tej przyczyny Prusy bały się arbitralnego rozwiązania kwestii przynależności dekanatów pszczyńskiego i bytomskiego aż do roku $1818^{15}$.

To wszystko powodowało, że po wcieleniu Śląska do Prus władze pruskie zastosowały odmienną politykę państwa wobec Kościoła katolickiego na tych ziemiach. Za Habsburgów Kościół był na tych ziemiach instytucją uprzywilejowaną. Przedstawiciele Kościoła zajmowali wysokie stanowiska w państwie. Król Fryderyk II wprowadził na tych ziemiach równouprawnienie religii. Zgodnie z pruską zasadą dążono do podporządkowania spraw Kościola państwu. Wprowadzono państwowa kontrolę, ograniczano wpływ Stolicy Apostolskiej na sprawy miejscowego Kościoła, zniesiono zależność zakonów od zagranicznych przełożonych, dóbr kościelnych nie kasowano, ale nałożono na nie pięćdziesięcioprocentowy podatek. Cała gospodarkę kościoła poddano pod kontrolę państwową. Zakazano ogłaszania bulli papieskich. Od kandydata wstępującego do stanu duchownego żądano zezwolenia rządowego. Wszystkie wakaty kościelne mogły być dopiero obsadzane po zatwierdzeniu odpowiednich władz państwowych. Te wszystkie posunięcia bardzo ograniczały działanie duchowieństwa śląskiego, jednak zachowano jego bazę materialną ${ }^{17}$.

Stosując politykę ograniczania swobody Kościoła na Śląsku rząd pruski nie zaniechał starań zmierzających do zwolnienia dekanatów bytomskiego i pszczyńskiego spod władzy biskupów krakowskich. Zaraz po pierwszym rozbiorze, 4 I 1773 r., władze pruskie zażądały od biskupa krakowskiego Kajetana Sołtyka nadania szerszych uprawnień dla dziekanów: bytomskiego i pszczyńskiego. Uczynił to dopiero administrator diecezji krakowskiej bp Michał Poniatowski, kiedy dekretem z dnia 12 II 1784 r. mianował ks. Franciszka Bartuzela dziekanem bytomskim. Jemu to zlecił bp Poniatowski kontrolę nad moralną stroną życia zarówno duchownych, jak i wiernych. Odtąd dziekan bytomski mógł zwoływać kongregacje dekanalne, przeprowadzać wizytacje parafialne każdego roku. Te same uprawnienia otrzymał 23 IV 1785 r. dziekan pszczyński ks. Tomasz Trzebień. W 1787 r. bp Poniatowski mianowal dwóch sędziów prosynodalnych dla rozpatrzenia zaża-

${ }^{13}$ N. Davies, R. M o or house, Portret miasta środkowoeuropejskiego. Wroclaw, Kraków 2002, s. 228-236.

${ }_{14}$ J. W y s o c k i, Kościól katolicki pod zaborem pruskim (1772-1815), [w:] Historia Kosciola..., dz. cyt., t. 2, cz. 1, s. 129.

${ }^{15} \mathrm{~K}$. D o l a, Katalog arcybiskupów i biskupów rezydencjalnych metropolii i diecezji polskich obrzadku rzymskokatolickiego do czasów współczesnych, [w:] Historia Kościola..., dz. cyt., t. 2, cz. 2, s. 302-303.

${ }_{16}^{16}$ B. K u mo r, Ustrój i organizacja Kościola polskiego, dz. cyt., s. 183

${ }^{17} \mathrm{~J}$. W y s o c k i, Kościól katolicki pod zaborem pruskim..., dz. cyt., t. 2, cz. 1, s. 130. 
leń kapituły wrocławskiej co do obsadzenia komendarza w Mikołowie, ks. Ludwika Kosmeli. Tymi sędziami prosynodalnymi byli: ks. Jan Paszkowski, proboszcz w Lędzinach i ks. Jan Zychoń, proboszcz z Bierunia.

Na przestrzeni kolejnych lat (1788-1795) dziekan bytomski ks. Franciszek Bartuzel otrzymal kolejne nowe uprawnienia od biskupa krakowskiego. W $1788 \mathrm{r}$. były to nowe kompetencje dotyczace małżeństwa. Od 1790 r. mógł wymierzać kary duchowne, na 6 miesięcy mianować administratorów parafii i przekazywać jurysdykcję kościelną komendarzowi i spowiednikom.

W interesującym nas tu okresie nie obyło się też bez ingerencji diecezji wroclawskiej w sprawy tych dekanatów. W 1789 r. sufragan wrocławski Antoni Ruthhirch, będąc w tym czasie delegatem apostolskim dla terytorium diecezji wrocławskiej, ogłosił tu redukcję świąt kościelnych. Owo rozporządzenie papieża Klemensa XIV wprowadzono w życie w Prusach z dniem 24 VI 1772 r.

Mimo takiej właśnie „próby sił” biskup krakowski dalej spełniał bezpośrednią jurysdykcję nad tymi dekanatami. Biskup krakowski Pawel Turski 14 III 1791 r. przeprowadził redukcję świąt dla parafii Bogucice. Umieścił nowego proboszcza w Tarnowskich Górach (22 VIII 1792) i w Bytomiu (21 III 1794). Tenże biskup przyjął też rezygnację dziekana pszczyńskiego ks. Sebastiana Niemczyńskiego. W lutym 1792 r. delegował on uprawnienia wizytatora generalnego ks. Franciszkowi Bartuzelowi, dziekanowi bytomskiemu, który wobec powyższego wizytację przeprowadził w obu dekanatach krakowskich na Ślasku. W roku 1798 bp Turski upoważnił ks. Pawła Irzyczyka, proboszcza w Mysłowicach, do złożenia w jego imieniu homagium królowi pruskiemu ${ }^{18}$.

W maju $1797 \mathrm{r}$. departament spraw zagranicznych w Berlinie przyjał projekt pozostawienia dekanatów bytomskiego i pszczyńskiego przy diecezji krakowskiej. Ta decyzja uwarunkowana była lękiem Prus przed decyzją Austrii wobec analogicznej sytuacji biskupstwa wrocławskiego, które posiadało swoje liczne dobra i parafie po stronie Śląska austriackiego. Sytuację skomplikowało mianowanie ks. Bartuzela oficjałem dla terenów dekanatu bytomskiego i pszczyńskiego przez bp. Pawła Turskiego dekretem z dnia 4 X 1797 r. Nominacja ta obejmowała również te tereny diecezji krakowskiej, które weszły po II i III rozbiorze w skład państwa pruskiego. Spowodowało to przeszłomiesięczną debatę $\mathrm{w}$ departamencie spraw zagranicznych. W jej wyniku rząd pruski postanowił uznać wybór ks. Franciszka Bartuzela na oficjała tylko $\mathrm{w}$ odniesieniu do terytorium dekanatu bytomskiego i pszczyńskiego.

Oba dekanaty pozostawały pod bezpośrednią jurysdykcją biskupa krakowskiego do 22 X $1811 \mathrm{r}$. Wtedy to biskup krakowski Andrzej Gawroński w zamian za otrzymane uprawnienia jurydyczne nad okręgiem Częstochowy i Nowego Ślaska przekazał jurysdykcję nad dekanatem bytomskim ${ }^{19}$ i pszczyńskim biskupowi wrocławskiemu Józefowi Hohenlohemu Powyższe zmiany miały charakter tymczasowy ${ }^{20}$.

${ }_{18}^{18}$ B. K u mo r, Dzieje diecezji krakowskiej..., dz. cyt., t. 1, s. 132-133.

${ }^{19}$ W 1789 r. księstwo siewierskie zostało włączone do Rzeczypospolitej. W związku z tą zmianą przynależności terytorialnej w $1791 \mathrm{r}$. biskup krakowski $\mathrm{P}$. Turski utworzył z parafii dekanatu lelowskiego i parafii księstwa siewierskiego 4 nowe dekanaty. Znaczyło to, że parafie Księstwa Siewierskiego zostały wyłączone z dekanatu bytomskiego.

${ }^{20}$ B. K u m o r, Ustrój i organizacja Kościola polskiego..., dz. cyt., s. 182-185. 
Ostatecznie losy przynależności terytorialnej dekanatu bytomskiego i pszczyńskiego rozstrzygały się w latach 1816-1821. Prowadzono wówczas rozmowy między pelnomocnikiem rządu pruskiego Nibuhrem i kard. Herkulesem Consalvim, przedstawicielem Stolicy Apostolskiej dotyczące reorganizacji administracji kościelnej w Prusach. Na mocy bulli papieskiej De salute animarum z 16 VII 1821 roku dekanat bytomski i pszczyński zostały włączone do diecezji wrocławskiej ${ }^{21}$.

Z pogranicza kościelnego diecezji krakowskiej i diecezji wrocławskiej przełomu XVIII i XIX w. do omówienia pozostały jeszcze tereny okręgu Częstochowy i Nowego Śląska. Po II rozbiorze Prusy otrzymały północno-zachodnie ziemie województwa krakowskiego. Była to Częstochowa z najbliższymi okolicami, które zostały wcielone do prowincji Prusy Poludniowe. Otrzymały one status powiatu. $\mathrm{Na}$ tym obszarze było kilka miast: Częstochowa, Kłobuck i Mstów. Po decyzjach państw zaborczych z dnia $24 \times 1795$ r., kiedy to zapadła decyzja całkowitej likwidacji Rzeczypospolitej (III rozbiór), Prusy otrzymały część ziem zachodnich powiatu lelowskiego i małe skrawki powiatu krakowskiego (Sławków) i książęcego (Szczekociny). Te ziemie otrzymały nazwę Nowy Śląsk. Było to terytorium w źródliskowym dorzeczu Warty. Na zachodzie określata je dawna granica śląska, na południu granica ta biegła Biała Przemsza, a na wschodzie dochodziło do rzeki Pilicy. Powierzchnia tego nowego tworu administracyjnego wynosiła $2230 \mathrm{~km}^{2}$. Na tym terytorium były następujące miasta i miasteczka: Będzin, Czeladź, Janów, Koziegłowy, Kromołów, Lelów, Modrzejów, Mrzygłód, Niwka, Ogrodzieniec, Olsztyn, Pilica, Siewierz, Sławków, Szczekociny, Włodowice, Żarki ${ }^{22}$. Obszar Nowego Śląska został przez władze pruskie podzielony na dwa powiaty: siewierski i pilicki. Łącznie obszar Nowego Śląska obejmowal 264 wsie oraz 17 miast i miasteczek. Na dawny powiat siewierski przypadały 102 wsie i 9 miast, a powiat pilicki składał się ze 162 wsi i 8 miast. Spośród nich 9 było miastami królewskimi, a 8 należało do dóbr szlacheckich. $Z$ tych ostatnich Janów nie miał własnego kościoła (jedynie kaplicę) i należał do parafii Potok. Poza tym miasta Modrzejów i Niwka także nie miały własnych kościołów ${ }^{23}$.

Pod względem organizacji kościelnej z czasów przedrozbiorowych (1786) były to 32 parafie $z$ prepozytury pilickiej ${ }^{24}$ należące do dekanatu lelowskiego: Biała (352 wiernych), Częstochowa (4543), Drocholin (289), Irządze (2504), Kłobuck (4879), Konopiska (1677), Kroczyce (1264), Kromołów (2048), Lelów (999), Lelów Stary (1735), Miedźno (1097), Mrzygłód (1965), Mstów (?), Nakło (1479), Niegowa (1272), Ogrodzieniec (929), Olsztyn (898), Poczesna (1307), Podlesie (374), Potok (1020), Przybynów (1402), Przyrów (1475), Przystań (790), Rokitno (519), Skarzyce (436), Szczekociny (1739), Truskolasy (3864), Wilkowisko (357), Włodowice (1938), Zrębice (616), Żarki (1969), Żóraw (903). Ogółem w tych parafiach

${ }^{21}$ Tamże, s. 185-186.

22 J. J a n c zak, Ziemia siewierska w okresie pruskim (1795-1806/1807), [w:] Siewierz. Czeladź. Kozieglowy..., dz. cyt., s. 615 n.; J. Z w i ą z e k, Komisariat siewierski w diecezji wroctawskiej (1797-1818), [w:] Tysiacletnie dziedzictwo kulturowe diecezji wroclawskiej, Katowice 2000 , s. 251-252.

${ }^{23}$ J. J a n c z a k, Ziemia siewierska w okresie pruskim..., dz. cyt., s. 617; F. M o r o ń, Proces ksztaltowania wschodniej granicy biskupstwa wroctawskiego na tle wydarzeń politycznych przelomu XVIII i XIX w. Przyczynek do genezy ustalen bulli "De salutare animarum", „Śląskie Studia Historyczno-Teologiczne" 1971, t. 4, s. 213 n.

${ }^{24}$ P. N a t a n e k, Organizacja terytorialna diecezji krakowskiej..., dz. cyt., s. $13 \mathrm{n}$. 
mieszkało 45824 wiernych $^{25}$. Poza terytorium Prus, po prawej stronie Pilicy znalazły się 3 parafie $z$ tego dekanatu: ${ }^{26}$ Goleniowy (574), Obiechów (981) i Przyłęk (389) - czyli 1945 wiernych $^{27}$. Nadto na terenie dekanatu siewierskiego, który należał do archidiakonatu krakowskiego, znajdowało się 12 parafii: Będzin (1665 - liczba ludności), Chruszczobród (1085), Ciaggowice (1665), Czeladź (1807), Gołonóg (1695), Grodziec (1061), Koziegłowy Nowe (3102), Koziegłowy Stare (2628), Saczów (1530), Siemonia (1323), Siewierz (2775), Targoszyce (1041), Wojkowice $(1478)^{28}$. Na terytorium dekanatu siewierskiego mieszkało 22798 wiernych $^{29}$. Ponadto $\mathrm{z}$ dekanatu wolbromskiego tworzącego achidiakonat pilecki $\mathrm{w}$ terytorium Nowego Ślaska weszły 3 parafie: Giebło (785), Kidów (625), Pilica (2810) ${ }^{30}$. Na terytorium Nowego Śląska znalazła się także parafia Sławków (3927) z dekanatu nowogórskiego; z archidiakonatu krakowskiego mieszkało w tych parafiach 4220 wiemych. Tak więc pod koniec lat dziewięćdziesiątych XVIII w. na terytorium nazwanym później Nowy Śląsk mieszkało 76769 wiernych w 48 parafiach $^{31}$.

Za czasów bp. Pawła Turskiego (1790-1800) już na początku jego pasterzowania podjęto pewne kroki zmierzające do podziału rozległego dekanatu lelowskiego i utworzenia diecezji częstochowskiej na północno-zachodnim terytorium diecezji krakowskiej ${ }^{32}$. Tendencje zmierzające do reorganizacji ustroju terytorialnego diecezji krakowskiej były już realizowane w latach 1768-1786, kiedy na terytorium tejże diecezji utworzono 3 sufraganaty: w Lublinie (1768), w Sandomierzu (1786), w Krakowie (1786) ${ }^{33}$. Podział dekanatu lelowskiego i nowa reorganizacja dekanatu siewierskiego miały miejsce w dniu 22 XI $1791 \mathrm{r}$. Wtedy to z polecenia bp. Turskiego dziekan lelowski ks. Józef Rudzki, mający w zarządzie dwie parafie: Kromołów i Skarżyce, zwołal kongregację dla dekanatu lelowskiego. Spotkanie miało miejsce przy kościele parafialnym w Żarkach. Zebrane duchowieństwo zostało poinformowane o podziale dekanatu lelowskiego na 4 dekanaty: częstochowski, przyrowski, szczekociński i lelowskı w nowych granıcach. Wyznaczenie Przyrowa i Szczekocin na siedziby nowych dekanatów już w krótkim czasie okazało się mało trafna. Te małe miasteczka położone na skrajach swych dekanatów i daleko od traktów komunikacyjnych nie wytrzymały próby czasu ${ }^{34}$. Nie bez znaczenia były także dążenia władz pruskich do ujednolicenia na tych ziemiach po III rozbiorze struktur państwowych i kościelnych. Stąd też granice nowych trzech dekanatów: częstochowskiego, pilickiego i siewierskiego, prawie całkowicie pokrywały się z granicami powiatów. Dekanat częstochowski obejmowal 11 parafii: Biała, Częstochowa, Kłobuck, Krzepice ${ }^{35}$, Miedźno, Poczesna,

${ }^{25} \mathrm{P}$. N a t a n e k, Ustrój i organizacja diecezji krakowskiej..., dz. cyt., t. 1, s. 49-50.

${ }^{26}$ Tamze, t. 3, mapa: Diecezja kikowska 1772 na podstawivic dañych 1776 i 1786.

${ }^{27}$ Tamże, t. 1, s. 49-50.

${ }^{28}$ Tamże, s. 30.

${ }^{29}$ Tamże.

${ }^{30}$ Tamize, t. 1, s. 45.

${ }^{31}$ Tamże, s. 29.

${ }^{32} \mathrm{~J} . \mathrm{Z}$ w i ą z e k, Komisariat siewierski w diecezji wroctawskiej (1797-1818), dz. cyt., s. 255.

${ }^{33}$ P. N a t a n e k, Organizacja terytorialna diecezji krakowskiej..., dz. cyt., s. 11.

${ }^{34} \mathrm{~J}$. Zwiazek, Komisariat siewierski w diecezji wroctawskiej, s. 256.

${ }^{35} \mathrm{~W}$ okresie przedrozbiorowym należała ona do archidiecezji gnieźnieńskiej, choć utworzona była z parafii Kłobuck należącej do diecezji krakowskiej. Zob. J. Z w i ą z e k, Krzepice, [w:] Encyklopedia katolicka, Lublin 2002, k. 1443. 
Przyrów, Przystań, Truskolasy, Wilkowiecko, Żuraw. Dekanat ten należał do prowincji Prus Południowych. Na dekanat pilicki składały się 22 parafie: Ciagowice, Drochlin, Giegło, Irządze, Kidów, Kroczyce, Klimontów, Lelów, Lelów Stary, Nakło, Niegowa, Niegowice, Ogrodzieniec, Pilica, Podlesie, Potok, Przybynów, Rokitno, Skarżyce, Szczekociny, Wlodowice i Żarki. Dekanat siewierski w swych historycznych granicach 12 parafii został poszerzony o 3 nowe $\mathrm{z}$ dawnego dekanatu lelowskiego i 1 parafię z dekanatu nowogórskiego. A zatem tworzyło go 15 parafii: Będzin, Chruszczobród, Czeladź, Gołonóg, Koziegłowy, Koziegłowy Stare, Mrzyglód (dekanat lelowski), Olsztyn (dekanat lelowski), Sączów, Siemonia, Siewierz, Sławków (dekanat nowogórski), Targoszyce, Wojkowice i Zrębice (dekanat lelowski). Ponadto $\mathrm{w}$ dekanacie pilickim znajdǫwały się 2 , a w dekanacie częstochowskim 1 filia. W omawianym okresie do dekanatu siewierskiego przylączona została parafia Chełm $z$ dekanatu pszczyńskiego ${ }^{36}$. Łącznie więc na tym terytorium było 51 parafii i 3 filie. W obrębie parafii znajdowały się zakony: w Częstochowie - paulini ( 3 domy), w Leśniowie - paulini, w Pilicy - penitencjarze (do kasaty w 1800 r.), w Przyrowie - bemardyni, w Kłobucku - kanonicy regularni laterańscy $^{37}$. Na terenie dekanatu siewierskiego nie znajdował się żaden klasztor.

$\mathrm{Na}$ terenach okręgu częstochowskiego i Nowego Śląska od momentu przejęcia władzy przez Prusy rozpoczął się proces niemieckiej kolonizacji. Na te ziemie zaczęły przybywać liczne grupy kolonistów pruskich, zakładających tu własne wsie. W celu pozyskania miejscowej ludności władze pruskie już na początku przeprowadziły ochronne szczepienia przeciw ospie. Poprzez bezpośrednie połączenie z sąsiednim Śląskiem zwiększył się od zaraz zbyt na miejscowe produkty i surowce. To zaś umożliwiło zwiększenie ilości nowych miejsc pracy i pogłębienie więzi społecznych. Dążąc do integracji władze pruskie nie utrudniały miejscowej ludności wypełniania praktyk religijnych. Także miejscowemu duchowieństwu nie czyniono przeszkód w pracy duszpasterskiej. Ograniczenia wprowadzano dopiero później. Dla pozyskania duchowieństwa i mieszkańców tych ziem w dniu 28 X 1793 r. do Częstochowy przybył sam król pruski Fryderyk Wilhelm II. W klasztorze jasnogórskin dostojny gość przebywał 4 dni, biorąc nawet udział w mszy św. i ,swoją obecnością przyozdobić je aż do zdumienia przytomnych raczył",38.

Przejęte tereny diecezji krakowskiej zostały przez władze pruskie na mocy postanowień rozbiorowych odcięte od zarządu diecezjalnego w Krakowie. Dlatego podjęto intensywne starania mające na celu zaprowadzenie na nowo podporządkowanych ziemiach niemieckiej organizacji kościelnej i przekazanie zarządu nad tymi dekanatami jednemu z krajowych biskupów. Aby tego dokonać, rząd pruski musiał uzyskać kościelne usankcjonowanie wyłączenia tych dekanatów spod jurysdykcji biskupa krakowskiego. Początkowo władze wysuwały projekt podporządkowania dekanatów: częstochowskiego, pilickiego i siewierskiego pod zarząd arcybiskupa gnieźnieńskiego Ignacego Krasickiego. Za tym rozwiązaniem przemawial fakt graniczenia dekanatu częstochowskiego $z$ archidiecezja gnieźnieńską $^{39}$. Jeszcze 25 IV 1797 r. Departament Spraw Zagranicznych rządu pruskiego

\footnotetext{
${ }^{36} \mathrm{~J}$. Z w i ą z e k, Komisariat siewierski w diecezji wroclawskiej, dz. cyt., s. 256-257.

${ }^{37} \mathrm{P} . \mathrm{N}$ a t a n e k, Ustrój i organizacja diecezji krakowskiej..., dz. cyt., t. 2, s. 609-614.

${ }^{38} \mathrm{~J}$. Z w i ą z e k, Komisariat siewierski w diecezji wroctawskiej, dz. cyt., s. 252-254

${ }^{39}$ B. K u m o r, Brewe papieskie wlaczajace Nowy Slask do diecezji wroclawskiej, Archiwa, Biblioteki i Muzea Kościelne 1965, t. 16, s. 311-312.
} 
proponował przydzielenie tych terenów do archidiecezji gnieźnieńskiej i diecezji wrocławskiej ${ }^{40}$. Jednak uwarunkowania polityczne spowodowały, że te plany zostały szybko zaniechane. $Z$ myślą o procesie scalania zaborca pruski wolał przyłączyć te czysto polskie etniczne ziemie do diecezji wrocławskiej, gdzie żywioł i kultura niemiecka były dominujące

Konwencja petersburska zawarta między państwami zaborczymi w dniu 26 I 1797 r. zakładała dostosowanie granic dawnych struktur kościelnych byłej już Rzeczypospolitej do granic państw zaborczych ${ }^{41}$. Miało to służyć ułatwieniu kontroli Kościoła przez państwo, a zarazem zatrzeć wszelkie możliwości przypominania tego, co stanowiło państwo polskie z czasów przedrozbiorowych ${ }^{42}$. W wyniku podjętych w Petersburgu postanowień władze pruskie podjęły starania mające na celu uregulowanie prawno-kościelne statusu omawianych dekanatów. Brak decyzji ze strony Stolicy Apostolskiej uniemożliwiał natychmiastowe rozwiązanie tej kwestii. W podobnych decyzjach Stolica Apostolska nigdy jednak nie wykazywała pośpiechu. Aby uzyskać odpowiednią zgodę papieską rząd pruski musiał najpierw uzyskać od biskupa krakowskiego przekazanie jego jurysdykcji na te tereny biskupowi wrocławskiemu. Tu trzeba nadmienić, że rozwiązywanie kwestii przynależności kościelnej wspomnianych trzech dekanatów szło $\mathrm{w}$ parze $\mathrm{z}$ rozwiązywaniem przynależności terytorialnej dekanatów bytomskiego i pszczyńskiego. Należy też dodać, że biskup krakowski Paweł Turski, wykorzystując wszystkie możliwości dyplomatyczno-kościelne, do końca bronil ich przynależności do diecezji krakowskiej. Jak już wspominano wyżej - omawiając przynależność terytorialną dekanatów bytomskiego i pszczyńskiego - bp Turski pokrzyżował wstępne plany rządu pruskiego. Mianowicie mianował 4 X 1797 r. dziekana bytomskiego ks. Bartuzela oficjałem nie tylko na dekanaty bytomski i pszczyński, ale i na te tereny diecezji krakowskiej, które Prusy zagarnęly w II i III rozbiorze. Rząd pruski usankcjonował jego decyzję dla okręgu dekanatu bytomskiego i pszczyńskiego, nie godząc się przy tym na okręg Częstochowy i Nowego Śląska ${ }^{43} .7$ XI $1797 \mathrm{r}$. Departament Spraw Zagranicznych poddał te dekanaty: częstochowski, pilicki i siewierski pod zarząd diecezji wrocławskiej. Trzeba zaznaczyć, że biskup wrocławski Józef Hohenlohe bez żadnych zastrzeżeń przyjmował podobne ingerencje władz pruskich w sprawy kościelne, co umożliwiało mu spokojne pełnienie posługi biskupiej na podporzadkowanym obszarze ${ }^{44}$. Takie rozwiązanie pozwoliło na przyjęcie kompromisu przez bp. Turskiego, który na początku 1798 r. przekazał jurysdykcję kościelna nad tymi terenami biskupowi wrocławskiemu.

A zatem - 2 dekanaty: bytomski i pszczyński pozostawały przy diecezji krakowskiej, a 3 dekanaty: częstochowski, pilicki i siewierski przechodzily pod jurysdykcję biskupa wrocławskiego. Fakt, że po stronie austriackiej biskup wrocławski posiadał swoją jurysdykcję na Śląsku Cieszyńskim i w okolicach Głuchołaz, zaważył na tym, iż Prusy - obawiając się arbitralnego rozwiązania kwestii przynależności tych dekanatów - nie parły do ostatecznego rozwiązania ${ }^{45}$. Dla

\footnotetext{
${ }^{40}$ B. K u mor, Ustrój i organizacja Kościola polskiego..., dz. cyt., s. 183

${ }^{41}$ J. J a n c z a k, Ziemia siewierska w okresie pruskim..., dz. cyt., s. 619.

${ }^{42} \mathrm{~J} . \mathrm{Z}$ w i a z e k, Komisariat siewierski w diecezji wroctawskiej..., dz. cyt., s. 257.

${ }^{43}$ B. K u mo r, Ustrój i organizacja Kościota polskiego..., dz. cyt., s. 183.

${ }^{44} \mathrm{~J}$. Z w i ą z e k, Komisariat siewierski $w$ diecezji wroctawskiej..., dz. cyt., s. 259.

${ }^{45}$ B. K u mor, Ustrój i organizacja Kościota polskiego..., dz. cyt., s. 183.
} 
usankcjonowania swojej decyzji z dnia 7 XI 1797 r., przekazującej dekanaty częstochowski, pilicki i siewierski pod jurysdykcję biskupa wrocławskiego, rząd pruski wystapił do rządu austriackiego o zaaprobowanie powyższej zmiany granic diecezjalnych. Zgoda nadeszła z Wiednia w dniu $14 \mathrm{~V} 1798$ r. Jednak wszystkie te rozwiązania mogły mieć charakter tylko tymczasowy, gdyż dla ich trwałego usankcjonowania potrzebna była zgoda Stolicy Apostolskiej. Nie zważając na to biskup wrocławski jeszcze przed papieskim potwierdzeniem owego stanu rzeczy zaprowadził na nowym terenie wrocławskie prawodawstwo kościelne. Wydanym przez siebie dekretem z dnia 11 IV 1799 r. ustanowil komisariat siewierski. Taka struktura (nazewnictwo nawet) nie była znana w czasach staropolskich na terytorium diecezji krakowskiej. Jej odpowiednikami na trenie diecezji krakowskiej były archidiakonaty czy też prepozytury. Nowy komisariat pełnił też funkcję oficjalatu okręgowego ${ }^{46}$. Odtąd zmianie uległo również nazewnictwo dekanatu, zastępując nazwę dekanat archiprezbiteratem ${ }^{47}$.

Komisarzem komisariatu siewierskiego został kapłan diecezji krakowskiej ks. dr Marcin Siemieński, proboszcz z Koziegłówek. Pochodził z Wielkopolski. Zasłużony dla diecezji krakowskiej, w której zinwentaryzował akta konsystorza generalnego za lata 1408-1795. Uczestniczył w spisach ludności diecezji krakowskiej. Za rzetelna pracę otrzymał w nagrodę parafię Koziegłówki, gdzie jednak w posłudze duszpasterskiej wyręczał go komendarz. W $1797 \mathrm{r}$. zamieszkał na stałe w swojej beneficjalnej parafii, zrzekając się stanowisk kurialnych w Krakowie ${ }^{48}$.

Natychmiast po utworzeniu przez biskupa wrocławskiego komisariatu siewierskiego rząd pruski rozpoczął starania w Stolicy Apostolskiej o kościelne usankcjonowanie zaistniałego na terenach Nowego Śląska i okolic Częstochowy stanu. Wypadkową tych działań było brewe papieża Piusa VII Ad universem Dominici gregis $\mathrm{z}$ dnia 9 IX $1800 \mathrm{r}^{49}$

Biskup poznański Ignacy Raczyński (1793-1807) został wykonawcą papieskiego brewe. Komisariat siewierski został inkorporowany do diecezji wrocławskiej w dniu 5 V $1801 \mathrm{r}$. Miało to miejsce w kościele parafialnym w Zarkach w obecności bp. Raczyńskiego, któremu towarzyszył kanonik Mateusz Zmychanowski, przy udziale licznie zgromadzonego duchowieństwa tych dekanatów. Przybyłego biskupa w imieniu duchowieństwa witał komisarz siewierski ks. Marcin Siemieński. Po zakończeniu ceremonii bp Raczyński dokonał aktu włączenia komisariatu do diecezji wrocławskiej, a zebrane duchowieństwo złożyło nowemu ordynariuszowi przysięgę wierności, potwierdzoną dodatkowo podpisami. Po tej ceremonii zebrane duchowieństwo, w liczbie prawie 70 kapłanów, udało się na obiad do pobliskiego klasztoru paulińskiego w Leśniowie.

Nowy komisarz ks. Siemieński rozpoczał zarządzanie od wizytacji poszczególnych parafii. Mając wielkie doświadczenie wyniesione z pracy inwentaryzacyjnej w krakowskim konsystorzu, wizytacje te przeprowadzal bardzo dokładnie. Podczas każdej wizytacji zwracał uwagę na aspekt moralny życia księży, ale i na

${ }^{46}$ J. Z w i ą z e k, Komisariat siewierski $w$ diecezji wroctawskiej..., dz. cyt., s. 258; B K u m o r, Ustrój i organizacja Kościoła polskiego..., dz. cyt., s. 183.

${ }^{47}$ J. Z w i ą z e k, Komisariat siewierski w diecezji wroclawskiej..., dz. cyt., s. 259-260.

${ }^{48}$ Tamże, s. 258-259.

49 P. N a t a n e k, Ustrój i organizacja diecezji krakowskiej..., dz. cyt., t. 1, s. 55; B K u m o r, Ustrój i organizacja Kościoła polskiego..., dz. cyt., s. 183. 
stan kasy parafialnej, oraz stan budynku świątyni i pozostałych zabudowań przykościelnych. Wizytacje te były opisywane bardzo dokładnie, potwierdzane własnoręcznym podpisem proboszcza i miejscowego wójta. Kwestionariusz nadesłany $z$ Wrocławia nakreślał styl i formę wizytacji. W swoich relacjach ks. Siemieński starał się przedstawić rzeczywisty obraz praktyk religijnych w poszczególnych parafiach, broniąc polskiej formy pobożności - w opinii konsystorza wrocławskiego była to bowiem tylko folkloryzacja obrzędów religijnych. Ponadto wladze kościelne we Wrocławiu były przekonane, że pobożność katolicka w Polsce ma zbyt wiele elementów ludowych i ze liturgia jest nieprawidłowo odprawiana.

$\mathrm{Z}$ akt powizytacyjnych odczytać można wielkie zatroskanie ks. Siemieńskiego o dobro dusz. Księżom wikariuszom zalecał katechizowanie dzieci z odległych wsi. Kapłanom nakazywał sprawowanie sakramentów starannie, dokładnie i chętnie. Ojcom paulinom ze Starej Częstochowy zalecał zaprzestanie krytykowania $\mathrm{z}$ ambony zarządzeń władz pruskich. Zwracał uwagę na okazywanie szacunku Najświętszemu Sakramentowi także poprzez zadbanie o ozdobione i dobrze zabezpieczone tabernakulum ${ }^{50}$.

Poważnym wyzwaniem organizacyjnym dla ks. Siemieńskiego było organizowanie szkolnictwa elementamego pod nadzorem Kościoła. Szkolnictwo elementarne dla władz pruskich było istotnym etapem wychowania małych poddanych na lojalnych obywateli. Miało być ono nadzorowane przez władze kościelne. Wydane rozporządzenie królewskie z 18 V 1801 r. i instrukcja biskupa wrocławskiego Józefa Hohenlohego z 6 listopada tego roku nakładały na duchowieństwo obowiązki związane $\mathrm{z}$ organizacją i działalnością tych szkół. Mimo wielu zarządzeń proboszczowie niezbyt chętnie wciagali się w tę pracę, która łączyła się $z$ całym szeregiem nowych obowiazków ${ }^{51}$.

Powstały twór organizacyjny na dawnych północno-zachodnich krańcach diecezji krakowskiej nie przetrwał nadchodzącej nowej i do tego zmiennej sytuacji politycznej. W 1806 r. Prusy zostały rozgromione przez Napoleona. Na ziemie Nowego Sląska wkroczyła dywizja Henryka Dąbrowskiego. Z Siewierza por. Trembecki, podlegający gen. Dąbrowskiemu, uczynil główną kwaterę dla swoich wojsk. Traktat w Tylży z 7 VII 1807 r. powołał do istnienia Księstwo Warszawskie. Granice Księstwa nakreślone wówczas nie obejmowały ziem Nowego Śląska. Nastapiło to dopiero po zawarciu dodatkowego traktatu w Elblagu 10 listopada tego roku ${ }^{52}$.

W nieznanych bliżej okolicznościach ks. Siemieński przestał pełnić funkcję komisarza. Wiadomo natomiast, że już w 1807 r. przebywał w Gnieźnie u boku swego przyjaciela, arcybiskupa Ignacego Raczyńskiego. Formalnie zrzekł się funkcji komisarza dopiero w $1812 \mathrm{r}$. Zapewne było to uwarunkowane zmianami politycznymi i przejściem tych ziem pod zarząd Księstwa Warszawskiego - na ziemiach polskich taka forma administracyjna jak komisariat nie była znana ${ }^{53} . \mathrm{Na}$ żądanie władz Księstwa Warszawskiego i prymasa Raczyńskiego biskup wrocławski Hohenlohe zrzekł się swojej jurysdykcji na tych terenach, przekazując ją 22 X 1811 r. biskupowi krakowskiemu Andrzejowi Gawrońskiemu. W zamian bp

\footnotetext{
${ }^{50}$ J. Z w i ą z e k, Komisariat siewierski w diecezji wroctawskiej.., dz. cyt., s. 260-261.

${ }^{51}$ Tamże, s. 262-263.

52 J. J a n c z a k, Ziemia siewierska w okresie pruskim..., dz. cyt., s. 617.

${ }^{53}$ J. Z w i ą z e k, Komisariat siewierski w diecezji wroctawskiej..., dz. cyt., s. 264-265.
} 
Gawroński zrzekł się swojej jurysdykcji nad dekanatami bytomskim i pszczyńskim i przekazal ją biskupowi wrocławskiemu ${ }^{54}$.

Te rozporządzenia, jak już podkreślano, miały charakter tymczasowy. Dopiero bulla ${ }^{55}$ papieża Piusa VII Ex imposita nobis z 30 VI 1818 r. usankcjonowała te rozstrzygnięcia. Dekanat pilicki i siewierski powróciły do diecezji krakowskiej. Natomiast dekanat częstochowski włączony został do diecezji włocławskiej. W wyniku tych zmian $\mathrm{w}$ jego granice wprowadzono kilka parafii $\mathrm{z}$ archidiecezji gnieźnieńskiej z dekanatu brzeźnickiego i radomszczańskiego. Kilka parafii dekanatu częstochowskiego włączono do nowego dekanatu krzepickiego ${ }^{56}$.

\section{Church Borderland of Cracow and Wroclaw Diocese in Silesia at the Turn of the $19^{\text {th }}$ Century Summary}

The issue includes the territory of the decanates of Bytom and Pszczyna in Upper Silesia and the decanates of Siewierz and Lelow in the region of Częstochowa and New Silesia. All these decanates used to belong to the Cracow diocese although most of them were beyond the borders of Poland. Until 1741 all Silesia was under the Austrian rule. It was only after the Silesian war between Prussia and Austria in 1741 that Silesia was subjected to the Prussian rule. Soon after the first partition, on January 4,1773 , the Prussian authorities demanded that the Cracow bishop Kajetan Sołtyk grant powers for the Bytom and Pszczyna decanates. Finally, territorial affiliation of these two decanates was decided in the years 1816-1821. Talks were held then between Nibuhr, plenipotentiary of the Prussian government and cardinal Consalvi, representative of the Holy See, concerning reorganization of church administration in Prussia. By the powers of the papal bulla De salutare animarum of July 16, 1821 the decanates of Bytom and Pszczyna were incorporated into the Wrockaw diocese.

${ }_{55}^{54}$ B. K u m o r, Ustrój i organizacja Kościoła polskiego..., dz. cyt., s. 184.

55 Szerzej o tym zob. wyżej, przy omawianiu problematyki dekanatu bytomskiego j pszczyńskiego.

${ }^{56} \mathrm{~J}$. Z w i ąz e k, Komisariat siewierski w diecezji wrocławskiej..., dz. cyt., s. 264-265. 